\title{
KNOWLEDGE ON PHYSICAL ACTIVITY AND NUTRITION BEHAVIOURS IN PATIENTS WITH INCREASED BODY WEIGHT AND CARDIOVASCULAR DISEASES
}

\section{WIEDZA W ZAKRESIE AKTYWNOŚCI FIZYCZNEJ I NAWYKÓW ŻYWIENIOWYCH CHORYCH ZE ZWIĘKSZONĄ MASĄ CIAŁA I CHOROBAMI UKŁADU KRĄŻENIA}

\author{
Józefa Dąbek $^{1(\mathrm{~A}, \mathrm{D}, \mathrm{E})}$, Joanna Piotrkowicz ${ }^{1(\mathrm{~A}, \mathrm{C}, \mathrm{F})}$, Andrzej Michalski ${ }^{1(\mathrm{~B}, \mathrm{C}, \mathrm{F})}$, Dariusz Korzeń ${ }^{2(\mathrm{E}, \mathrm{F}, \mathrm{G})}$
}

${ }^{1}$ Department of Cardiology, School of Health Science in Katowice, Medical University of Silesia, Katowice, Poland ${ }^{2}$ Department of Anaesthesiology and Intensive Care with Cardiac Monitoring, Independent Public Clinical Hospital of the Silesian Medical University in Katowice, Leszek Giec Upper-Silesian Medical Centre, Poland

Authors' contribution Wkład autorów:

A. Study design/planning zaplanowanie badań

B. Data collection/entry zebranie danych

C. Data analysis/statistics dane - analiza i statystyki D. Data interpretation interpretacja danych E. Preparation of manuscript przygotowanie artykułu F. Literature analysis/search wyszukiwanie i analiza literatury G. Funds collection zebranie funduszy
Tables: 7

Figures: 1

References: 19

Submitted: 2017 March 21

Accepted: 2017 May 16

\section{Summary}

Background. Low physical activity and the increasing number of overweight and obese people contribute to the prevalence of cardiovascular diseases in society. Classic risk factors and improper lifestyle increase the risk of their occurrence, progression and mortality in patients. The aim of the study was assessment of physical activity and nutrition behaviours in people with abnormal body weight and cardiovascular diseases.

Material and methods. The study involved 152 patients including 70 men and 82 women aged 23-95 years (mean $55.4 \pm 14.04$ years). The study used the International Physical Activity Questionnaire IPAQ in its seven-day version and an original questionnaire. The data were collected in a database and Statistica v.10 was used for a statistical analysis.

Results. The average energy expenditure amounted to 1.422 MET. 50\% of the participant demonstrated sufficient physical activity, 36\% low, and only $14 \%$ high. Only $15 \%$ of the respondents did exercises. Despite being overweight and obese, $66 \%$ of the respondents did not follow a diet and only $17 \%$ of them consumed 5 meals a day.

Conclusions. Despite the occurrence of cardiovascular diseases and abnormal body weight, physical activity was low in the study group, and the knowledge in this regard was limited. In addition a significant number of respondents did not exhibit healthy behaviours.

Keywords: obesity, risk factors, cardiovascular diseases, physical activity

\section{Streszczenie}

Wprowadzenie. Niewystarczająca aktywność fizyczna oraz stały wzrost liczby osób z nadwagą i otyłością przyczyniają się do występowania w społeczeństwie chorób układu krążenia. Rozpowszechnienie klasycznych czynników ryzyka i nieodpowiedni styl życia zwiększają ryzyko ich wystepowania, progresji oraz odsetka śmiertelności wśród chorujących. Celem pracy była ocean aktywności fizycznej oraz nawyków żywieniowych chorych ze zwiększoną masą ciała i chorobami układu krążenia.

Materiał i metody. Zbadano 152 chorych, w tym: 70 mężczyzn i 82 kobiety w wieku 23-95 lat (średnio: $55.4 \pm 14.04$ ). Do badań wykorzystano autorski kwestionariusz ankiety, a do oceny aktywności fizycznej standaryzowany Międzynarodowy Kwestionariusz Aktywności Fizycznej w wersji siedmiodniowej. Analizę statystyczną wykonano przy użyciu programu Statistica v.10.0

Wyniki. Średni wydatek energetyczny badanych chorych wynosił 1.422 MET. Wśród nich, 50\% badanych uzyskało wystarczający poziom aktywności fizycznej, 36\% niski, a 14\% - wysoki. Spośród badanych 15\% respondentów uprawiało sport. Pomimo występującej nadwagi lub otyłości, $66 \%$ badanych nie stosowała diety, a jedynie $17 \%$ spożywało 5 posiłków dziennie

Wnioski. Pomimo występowania chorób układu krążenia oraz nieprawidłowej masy ciała aktywność fizyczna $\mathrm{w}$ badanej grupie była zbyt mała, a wiedza w tym zakresie niewystarczająca. Ponadto znaczna grupa badanych osób nie przestrzegała prawidłowych nawyków żywieniowych.

Słowa kluczowe: otyłość, czynniki ryzyka, choroby układu krążenia, aktywność fizyczna

Dąbek J, Piotrkowicz J, Michalski A, Korzeń D. Knowledge on physical activity and nutrition behaviours in patients with increased body weight and cardiovascular diseases. Health Prob Civil. 2018; 12(3): 196-203. https://doi.org/10.5114/hpc.2018.76520

Address for correspondence / Adres korespondencyjny: Joanna Piotrkowicz, Department of Cardiology, School of Health Science in Katowice, Medical University of Silesia, Katowice, Ziołowa 45/47, 40-635 Katowice, Poland, e-mail: joanna.piotrkowicz@gmail.com, phone: +48 322527407

Copyright: (C) Pope John Paul II State School of Higher Education in Biała Podlaska, Józefa Dąbek, Joanna Piotrkowicz, Andrzej Michalski, Dariusz Korzeń. This is an Open Access journal, all articles are distributed under the terms of the Creative Commons Attribution-NonCommercial-ShareAlike 4.0 International (CC BY-NC-SA 4.0) License (http://creativecommons.org/licenses/by-nc-sa/4.0/), allowing third parties to copy and redistribute the material in any medium or format and to remix, transform, and build upon the material, provided the original work is properly cited and states its license. 


\section{Introduction}

The development of technology and mechanisation contributed to a significant reduction of physical activity in society. The most common devices linked to daily use such as washing machine, dishwasher, elevators, mobile phones and public transport caused that people move less frequently. Insufficient physical activity in combination with the omnipresent stress, the fast pace of life, poor nutrition or use of drugs contributed to an increasing prevalence of cardiovascular diseases [1].

Cardiovascular diseases are the leading causes of death in the world [2]. While in 1960 cardiovascular incidence accounted for $23.4 \%$ deaths, in 2013 it was already 45,8\%. Projections for morbidity are also not optimistic. As the forecasts of the Central Statistical Office have shown, the number of deaths from cardiovascular causes in Poland will increase from 177 thousand (45.8\% of the total mortality) in 2013 to 218.9 thousand in 2050 (51.1\% of the overall mortality). To a large extent, the risk factors that contribute to the dissemination of cardiovascular diseases contribute can be divided into two groups: modifiable and non-modifiable [3].

The group of non-modifiable risk factors include age, sex, and positive family history, and the group of modifiable risk factors: smoking, hypertension, improper diet, stress, alcohol abuse, unsatisfactory physical activity, hypercholesterolemia, overweight, obesity and diabetes $[4,5,6,7]$. The presence of modifiable risk factors can be eliminated, and people can modify their habits and lead a healthy lifestyle. Then, such an elimination of risk factors reduces the risk of cardiovascular disease from 50 up to $70 \%[1,8]$.

The recommendations by American Heart Association on the prevention of cardiovascular diseases indicate that one of the significant factors is regular physical activity. Each type of exercise has a positive effect on risk factors of cardiovascular disease [9]. Daily physical activity leads to the reduction in cardiac load by slowing the heart rate in rest, lowering resting blood pressure, speeding up the return of the pulse rate after exercise to the resting level [10]. In addition, it improves emotional state and mental health, regulates body fat distribution and helps maintain a diet regimen.

Under the influence of regular exercise, there also occurs lower concentration of cholesterol, i.e. LDL, while the level of HDL, which has a significant effect of physical activity, increases. Consequently, physical activity combined with a healthy diet can help to keep the correct body weight or reduce its excess [11]. In the developed and developing countries, a significant increase in the number of the overweight or obese contributed to recognising obesity as a civilisation disease. It concerns not only older people who, for various reasons have limited their physical activity, but more and more often youth and younger persons, in particular children. The problem has become a global issue. In Europe, as many as $50-65 \%$ of the population have increased body weight, of which about $16 \%$ are obese. In Poland, 52\% men and 29\% women suffer from an increased body weight [12,13,14]. Overweight and obesity are in themselves risk factors for cardiovascular disease [15]. In patients who are burdened with cardiovascular diseases, overweight or obesity, incorrect nutrition habits, an unsatisfactory level of physical activity and coexisting diseases have negative influence on their prognosis.

The main aim of the study was an assessment of physical activity and nutrition behaviours in patients with increased body weight and cardiovascular diseases. Additionally, knowledge concerning physical activity, principles of proper nutrition and their application in daily life was assessed.

\section{Material and methods}

The study involved 152 patients including 70 men and 82 women aged from 23 to 95, average 55,4 $\pm 14,04$. Characteristics of the study group are shown in Table 1.

Table 1. General characteristics of the study group

\begin{tabular}{|c|c|c|c|c|}
\hline Variable & Average & Min & Max & SD \\
\hline Age [year] & 55.4 & 23 & 95 & 18.45 \\
\hline Body weight [kg] & 81.7 & 55 & 135 & 14.04 \\
\hline Height [m] & 1.69 & 1.48 & 1.96 & 0.097 \\
\hline BMI [kg/m $\left.\mathbf{m}^{2}\right]$ & 28.2 & 25 & 42 & 3.13 \\
\hline
\end{tabular}

The study was conducted at the Department of Physiotherapy and Hydrotherapy in MSWiA Hospital in Katowice, Poland. The study used the International Physical Activity Questionnaire (IPAQ), a seven-day self assessment format, and an original questionnaire.

The IPAQ consisted of 4 parts testing hard work, moderate work, walking and time spent sitting during the day. On the basis of the collected data, the total energy expenditure was calculated in MET (Metabolic Equiva- 
lent). The original questionnaire included 29 questions relating to physical activity, knowledge in this regard, nutrition behaviours and lifestyle of the surveyed participants. All the individuals expressed their agreement to participate in the examination. The inclusion criteria for the study were the occurrence of cardiovascular disease and a BMI above $25 \mathrm{~kg} / \mathrm{m} 2$. The data were collected in a database and for statistical analysis (Statistica v.10 was used).

\section{Results}

General characteristics of the study group patients with increased body mass and cardiovascular diseases

The general characteristics of the study group of patients with increased body mass and cardiovascular diseases are presented in Table 1.

The characteristics of the study group of patients with increased body mass and cardiovascular diseases regarding BMI are presented in Table 2.

Table 2. Characteristic of the study group regarding BMI

\begin{tabular}{|c|c|c|}
\hline Variable & $\mathrm{N}=152$ & $100 \%$ \\
\hline Underweight ( BMI < 18.5) & 0 & $0 \%$ \\
\hline Correct range (BMI 18.5-24.9) & 0 & $0 \%$ \\
\hline Overweight (BMI 25-29.9) & 118 & $78 \%$ \\
\hline Obesity Class I (BMI 30-34.9) & 30 & $20 \%$ \\
\hline Obesity Class II (BMI 35-39.9) & 2 & $1 \%$ \\
\hline Obesity Class III (BMI $\geq 40)$ & 2 & $1 \%$ \\
\hline
\end{tabular}

It turned out that body mass index exceeded $25 \mathrm{~kg} / \mathrm{m}^{2}$ in each person and every fifth tested individual was obese.

Table 3 presents characteristics of the study group of patients regarding the occurrence of cardiovascular diseases.

Table 3. Occurrence of cardiovascular diseases in the study group

\begin{tabular}{|c|c|c|}
\hline Variable & $\mathrm{N}=152$ & $100 \%$ \\
\hline Hypertension & 106 & $69 \%$ \\
\hline Coronary artery disease & 18 & $12 \%$ \\
\hline Myocardial infraction & 29 & $19 \%$ \\
\hline Coronary angioplasty & 12 & $8 \%$ \\
\hline Heart failure & 7 & $4.5 \%$ \\
\hline Valvulopathy & 13 & $8.5 \%$ \\
\hline Arrhythmia & 19 & $12.5 \%$ \\
\hline Peripheral vascular disease & 14 & $9 \%$ \\
\hline Stroke & 7 & $4.5 \%$ \\
\hline Other & 6 & $4 \%$ \\
\hline
\end{tabular}

Most patients in the study group, i.e. 106 (69\%), suffered from hypertension, subsequently myocardial infarction and coronary heart disease. A few patients had a stroke and were struggling with heart failure -7 persons $(4.5 \%)$.

\section{Physical activity of patients with increased body mass and cardiovascular diseases}

The characteristics of the study group with increased body mass and cardiovascular diseases took into account the data provided by the International Physical Activity Questionnaire: the load of hard work, moderate work, walking, total physical activity in MET (Metabolic Equivalent) and time spent sitting during the day. The data were shown in Table 4. 
Table 4. Characteristic of the study group taking into account data of IPAQ

\begin{tabular}{|c|c|c|c|c|}
\hline Variable & Average & Min & Max & SD \\
\hline Hard work (MET) & 333.4 & 0 & 4320 & 657.9 \\
\hline Moderate work (MET) & 338.2 & 0 & 6720 & 680.1 \\
\hline Walking (MET) & 746 & 0 & 5148 & 1020 \\
\hline Total Physical Activity (MET) & 1422 & 0 & 9200 & 1607.4 \\
\hline Sitting (min.) & 320 & 50 & 850 & 147 \\
\hline
\end{tabular}

The total energy expenditure in the study group was diverse and ranged from 0 to 9200 MET. Furthermore, the surveyed participants spent their time sitting even 14 hours a day.

Taking all the data of total energy expenditure into account, the surveyed participants were qualified into three groups, those demonstrating low, moderate and highly physically activity (Figure 1).

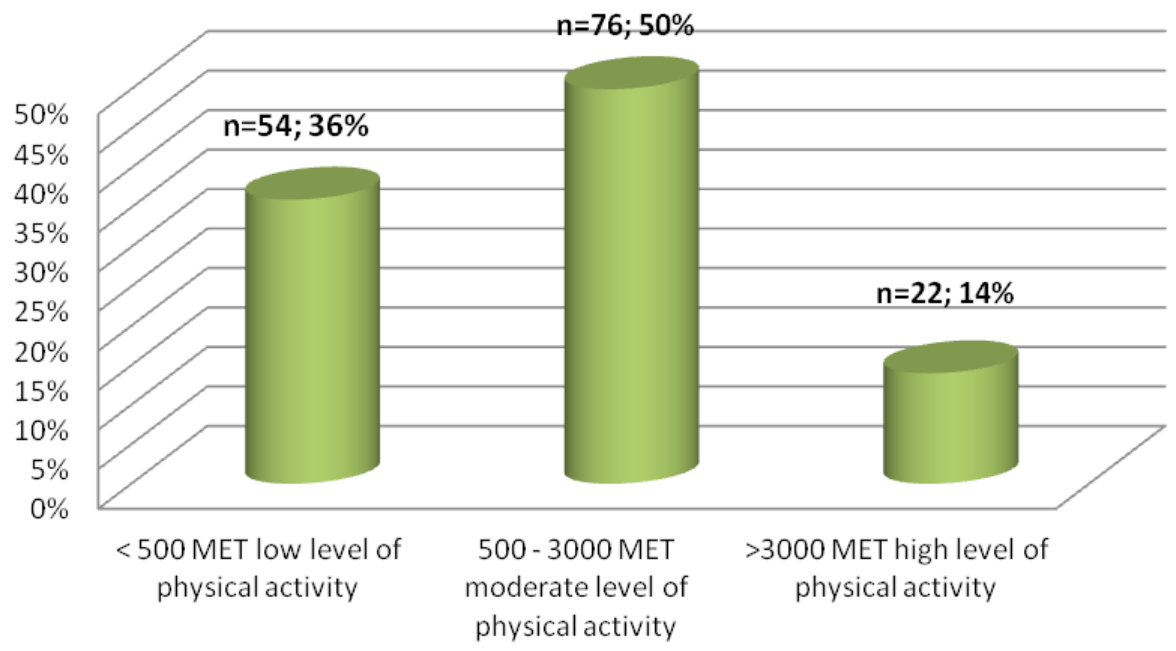

Figure 1. Characteristic of the study group regarding total physical activity based on IPAQ

The study indicated that, although half of the patients achieved a sufficient level of physical activity ranging from 500 to 3000 MET, the physical activity level of 54 respondents (36\%) was too low (less than 500 MET). Only 22 tested persons (14\%) achieved a high level of physical activity.

The characteristics of the study group of patients with increased body mass and cardiovascular diseases also measured the knowledge on the role of physical activity in the prevention of cardiovascular disease. The findings are presented in Table 5.

Table 5. Level of knowledge taking into account physical activity in study group

\begin{tabular}{|c|c|c|}
\hline Variable & $\mathbf{N = 1 5 2}$ & $\mathbf{1 0 0} \%$ \\
\hline Should patients which suffering from heart diseases be physically active? \\
\hline Yes & 137 & $90 \%$ \\
\hline No & 3 & $2 \%$ \\
\hline I don't know & 12 & $8 \%$ \\
\hline How often should people with cardiovascular disease be physically active? \\
\hline Just once a week & 15 & $10 \%$ \\
\hline Few days a week & 58 & $38 \%$ \\
\hline Everyday & 33 & $22 \%$ \\
\hline I don't know & 46 & $30 \%$ \\
\hline Two weeks & 6 & $4 \%$ \\
\hline At least a month & 21 & $14 \%$ \\
\hline At least three months & 47 & $31 \%$ \\
\hline I don't know & 78 & $51 \%$ \\
\hline
\end{tabular}




\begin{tabular}{|c|c|c|}
\hline \multicolumn{2}{|c|}{ How long should an exercise last? } \\
\hline At least 30 minutes & 96 & $63 \%$ \\
\hline At least 60 minutes & 13 & $8 \%$ \\
\hline Above 60 minutes & 2 & $1 \%$ \\
\hline I don't know & 41 & $27 \%$ \\
\hline
\end{tabular}

The characteristics of the study group with regard to activities performed during leisure time are shown in Table 6.

Table 6. Characteristic of the study group taking account preference of leisure time activities

\begin{tabular}{|c|c|c|}
\hline Variable & $\mathbf{N = 1 5 2}$ & $\mathbf{1 0 0} \%$ \\
\hline Watching TV & 91 & $60 \%$ \\
\hline Reading books & 50 & $33 \%$ \\
\hline Napping & 23 & $23 \%$ \\
\hline Solving crosswords & 35 & $17 \%$ \\
\hline Playing on computer & 26 & $28 \%$ \\
\hline Walking & 43 & $18 \%$ \\
\hline Morking in the garden & 27 & $23 \%$ \\
\hline Exercising & 35 & $15 \%$ \\
\hline Other & 23 & $0 \%$ \\
\hline
\end{tabular}

Only 23 patients from the study group (15\%) did exercises in leisure time, whereas 91 persons (60\%) watched TV or read a book - 50 respondents $(33 \%)$.

\section{Characteristics of the study group of patients with increased body mass and cardiovascular diseases regarding BMI}

The characteristics of the study group regarding assessment and control of body mass as well as dietary habits are presented in Table 7.

Table 7. Characteristic of the study group regarding assessment and control of body mass

\begin{tabular}{|c|c|c|}
\hline Variable & $\mathrm{N}=152$ & $100 \%$ \\
\hline Everyday & 5 & $3 \%$ \\
\hline Once a week & 15 & $10 \%$ \\
\hline Once a month & 36 & $24 \%$ \\
\hline Once of three months & 30 & $20 \%$ \\
\hline Semi-annually & 30 & $20 \%$ \\
\hline I do not control the process & 35 & $23 \%$ \\
\hline \multicolumn{3}{|c|}{ Subjective assessment of their own body weight } \\
\hline Correct & 47 & $31 \%$ \\
\hline Slightly too large & 74 & $49 \%$ \\
\hline Definitely too large & 17 & $11 \%$ \\
\hline I cannot determine it & 14 & $9 \%$ \\
\hline \multicolumn{3}{|c|}{ Using a diet } \\
\hline Yes & 52 & $34 \%$ \\
\hline No & 100 & $66 \%$ \\
\hline \multicolumn{3}{|c|}{ Regular eating } \\
\hline Yes & 37 & $25 \%$ \\
\hline No & 84 & $56 \%$ \\
\hline I do not pay attention & 29 & $19 \%$ \\
\hline \multicolumn{3}{|c|}{ Number of daily meals } \\
\hline 2 meals & 6 & $4 \%$ \\
\hline 3 meals & 54 & $36 \%$ \\
\hline
\end{tabular}




\begin{tabular}{|c|c|c|}
\hline 4 meals & 49 & $32 \%$ \\
\hline 5 meals & 26 & $17 \%$ \\
\hline I'm eating when I'm hungry & 17 \\
\hline \multicolumn{2}{|c|}{ Snacking between meals } \\
\hline Yes & 117 & $77 \%$ \\
\hline No & 35 & $23 \%$ \\
\hline
\end{tabular}

The examination of the study group showed that, despite overweight and obesity as well as cardiovascular diseases in the patients, 100 respondents (66\%) did not follow a diet, 117 (77\%) snacked between meals, and only $26(17 \%)$ ate five meals a day. Moreover, 47 patients (31\%) estimated their body weight as correct, although it was not the case, and 14 patients could not evaluate their body weight.

\section{Discussion}

The results of the studies on physical activity patients with cardiovascular diseases and increased body mass confirmed the findings documented in numerous publications, which shows that the level of physical activity in these groups of patients is too low. During an average week, the patient's expenditure for walking is on average 746 MET.

A one-time moderate physical activity lasted on average 37 minutes on three days a week. As for moderate work, average weekly energy expenditure was 338 MET per week.

One-time physical activity at the intensive level lasted on average 31 minutes for 2.9 days per week. The average weekly energy expenditure related to an intense activity amounted to 333 MET. Such a result is considered insufficient. Physical activity at moderate level was demonstrated by 100 patients (66\%). Intensive physical exercises were performed the least often, i.e. 67 (44\%) of the surveyed, which means that the majority of respondents did not do any exercises required to accelerate the pulse and breathing.

An average for the total weekly expenditure of energy amounted to 1417 MET. When compared to the scale of the IPAQ $Q$, the result seems sufficient, but it should be kept in mind that this average physical activity concerns all the respondents.

The sufficient level of physical activity was exhibited only by one in two patients. The results are consistent with those published in 2013 research in which Puciato et al. examined 2,053 people using the IPAQ short version, which showed that the level of physical activity during leisure time in the studied population was low [15]. Similar results were obtained in the study conducted by Wozniak et al., which assessed physical activity and diet behaviours of people with cardiovascular diseases. Most of the patients ( $81 \%$ women and $66 \%$ men) showed a sufficient level of physical activity, but their nutrition behaviours did not follow the recommendations [16]. However, the study by Woźniak et al. indicated a higher percentage of those who achieved a sufficient level of physical activity compared to our results. This may indicate that the prevalence of overweight or obesity in people with cardiovascular disease is an important factor which decreasing their physical activity. What seems comforting is the fact that $90 \%$ of the surveyed realize that patients with cardiovascular diseases should be physically active. There remains a very large group of patients who do not know this.

Further, the study assessed the number of meals consumed a day as well. It was shown that the numbers varied. Some patients consumed 2 meals: 6 (4\%); others 26 (17\%) - 5 meals, despite an increased body weight. The biggest groups of respondents consumed 3 meals- 54 persons (36\%); and 4 meals - 49 respondents (32\%). The results are consistent with the already mentioned research, which concludes that few people consume only 2 meals per day ( $3 \%$ of the respondents) or 5 meals (17\%). However, by far the most numerous groups of respondents consumed 3 meals $-46 \%$ of the respondents or $4-35 \%$ of the surveyed.

The study by Platta et al. assessing nutritional behaviours of patients with regard to prevention of cardiovascular diseases showed that $40 \%$ of the surveyed are overweight and $13 \%$ were patients in Obesity Class I, whereas 1\% - in Obesity Class II [17]. The results of the presented study are not consistent with our findings, maybe because the former group featured 118 overweight patients (77\%), which was twice higher than in our study. However, very similar results were recorded in terms of Obesity Class II, which was found in 30 of the respondents (19\%). The study showed that $2 \%$ of the patients could be classified as belonging to that class, which was close to our findings.

As for lifestyle and knowledge on healthy behaviours in obese people with hypertension, a publication from 2009 reported that up to $66.7 \%$ of the surveyed women and $87.1 \%$ of the men did not follow any diet, despite the increased weight and accompanying hypertension [18]. Interestingly, these results are consistent with our studies in which up to 100 of the surveyed patients (66\%) did not follow any diet despite increased body weight. 
It is worth emphasising that a significant number of patients in the study group also suffered from hypertension, which is regarded as a lifestyle disease related to one's diet, unhealthy lifestyle and insufficient knowledge on nutrition [19].

Thus, despite the fact that the half of the surveyed persons achieved a sufficient level of physical activity, their knowledge in this regard was limited. What is worse, they do not follow the healthy recommendation in their daily life. The burden of cardiovascular diseases, overweight and obesity adversely affects health outcomes in this group of patients and; therefore, the results of the presented studies point to a need of introducing health education programme in the groups with the same or similar disorders as those in the study group.

\section{Conclusions}

Basing on these results, the following conclusions have been formulated:

1. Physical activity of half of the patients with increased body weight and cardiovascular diseases was sufficient, although their knowledge in this regard was unsatisfactory.

2. Patients of the study group show incomplete knowledge on healthy behaviours and, in most cases, they did not follow them in daily life.

3. Most of the patients exhibited improper nutrition habits and did not pay attention to proper nutrition, which mainly contributes to their increased weight and, consequently, predisposes them to cardiovascular diseases.

4. Improper health behaviours and low physical activity in patients with increased body mass and cardiovascular diseases result not only from insufficient knowledge in this field but also a lack of desire and motivation to apply it in daily life.

\section{References:}

1. Perk J, De Backer G, Gohlke H, Graham I, Reiner Z, Verschuren WMM, et al. European Guidelines on cardiovascular disease prevention in clinical practice (version 2012). European Heart Journal. 2012; 33(13): 1635-1701. https://doi.org/10.1093/eurheartj/ehs092

2. Santulli G. Epidemiology of cardiovascular disease in the 21st century: updated numbers and updated facts. JCvD 2013; 1(1): 1-2.

3. Martín-Timón I, Sevillano-Collantes C, Segura-Galindo A, del Ca-izo-Gómez FJ. Type 2 diabetes and cardiovascular disease: Have all risk factors the same strength. World J Diabetes. 2014; 5(4): 444-470. https://doi.org/10.4239/wjd.v5.i4.444

4. Miller IM, Ellervik C, Yazdanyar S, Jemec GB. Meta-analysis of psoriasis, cardiovascular disease, and associated risk factors. Journal of the American Academy of Dermatology 2013; 69(6): 1014-1024. https://doi.org/10.1016/j.jaad.2013.06.053

5. Canto John JG, Kiefe CI, Rogers WJ, Peterson ED, Frederick PD, French WJ, et al. Number of coronary heart disease risk factors and mortality in patients with first myocardial infarction. Jama. 2011; 306(9): 21202127. https://doi.org/10.1001/jama.2011.1654

6. Daviglus Martha L, Talavera GA, Avilés-Santa ML, Allison M, Cai J, Criqui MH, et al. Prevalence of major cardiovascular risk factors and cardiovascular diseases among Hispanic/Latino individuals of diverse backgrounds in the United States. Jama. 2012; 308(17): 1775-1784. https://doi.org/10.1001/jama.2012.14517

7. Avery CL, Loehr LR, Baggett C, Chang PP, Kucharska-Newton AM, et al. The population burden of heart failure attributable to modifiable risk factors: the ARIC (Atherosclerosis Risk in Communities) study. Journal of the American College of Cardiology. 2012; 60(17): 1640-1646. https://doi.org/10.1016/j.jacc.2012.07.022

8. Buraczynski T, Gotlib J. Ocena wiedzy pacjentów w fazie rekonwalescencji po zabiegu angioplastyki tętnic wieńcowych na temat eliminowania czynników ryzyka choroby wieńcowej jako elementu prozdrowotnego stylu życia. Medycyna Ogólna i Nauki o Zdrowiu. 2014; 20(2): 199-207. https://doi.org/10.5604/20834543.1112238

9. Lavie CJ, McAuley PA, Church TS, Milani RV, Blair SN. Obesity and cardiovascular diseases: implications regarding fitness, fatness, and severity in the obesity paradox. Journal of the American College of Cardiology. 2014; 63(14): 1345-1354. https://doi.org/10.1016/j.jacc.2014.01.022

10. Pattyn N, Cornelissen VA, Eshghi SRT, Vanhees L. The effect of exercise on the cardiovascular risk factors constituting the metabolic syndrome. Sports Medicine 2013, 43(2): 121-133.

https://doi.org/10.1007/s40279-012-0003-z 
11. Kotseva K, Wood D, Backer GD, Bacquer DD. Use and effects of cardiac rehabilitation in patients with coronary heart disease: results from the EUROASPIRE III survey. European Journal of Preventive Cardiology. 2013; 20(5): 817-826. https://doi.org/10.1177/2047487312449591

12. Krzysztoszek J, Wierzejska E, Zielinska A. Obesity. An analysis of epidemiological and prognostic research. Archives of Medical Science. 2015; 11(1): 24-33. https://doi.org/10.5114/aoms.2013.37343

13. Przybylska D, Kurowska M, Przybylski P. Obesity and overweight in the developmental population. Hygiea Public Health. 2012; 47(1): 28 -35.

14. Ezzati, M, Riboli, E. Behavioral and dietary risk factors for noncommunicable diseases. New England Journal of Medicine. 2013; 369(10): 954-964. https://doi.org/10.1056/NEJMra1203528

15. Puciato D, Rozpara M, Mynarski W, Łoś, A, Królikowska B. Physical activity of adult residents of Katowice and the selected occupational and socio-economic conditions. Med Pr. 2013; 64(5), 649-657.

16. Woźniak A, Wawrzyniak A, Anyżewska A, Krotki M. Ocena aktywności fizycznej i sposobu żywienia osób z chorobami sercowo-naczyniowymi. Probl Hig Epidemiol. 2014; 95(2): 346-351.

17. Platta A, Żyngiel W. Assessment of nutritional behavior of women and men in the prevention of cardiovascular disease. Probl Hig Epidemiol. 2013; 94(3): 614-618.

18. Bronkowska M, Martynowicz H, Żmich H, Szuba A, Biernat J. Selected elements of life style and nutrition knowledge in obese patients with hypertension. Hypertension. 2009; 13(4): 266-274.

19. Schwab U, Lauritzen L, Tholstrup T, Haldorsson T, Riserus U, Uusitupa M, et al. Effect of the amount and type of dietary fat on cardiometabolic risk factors and risk of developing type-2 diabetes, cardiovascular disease, and cancer: a systematic review. Food \& Nutrition Research [Internet]. 2014 Jul 10 [cited 2018 Jun 12]. 58. Available from: http://foodandnutritionresearch.net/index.php/fnr/article/view/680.

https://doi.org/10.3402/fnr.v58.25145 